\title{
HUBUNGAN ANTARA ASI EKSLUSIF DAN PEMBERIAN MAKANAN PENDAMPING ASI (MP-ASI DENGAN STATUS GIZI PADA BAYI UMUR 7-12 BULAN DI PUSKESMAS KLUWUT
}

\author{
Hendri Pramifta ${ }^{1}$, Anggray Duvita Wahyani ${ }^{2 *}$, Yuniarti Dewi Rahmawati ${ }^{3}$ \\ 1,2,3 Program Studi Gizi, Fakultas Ilmu Kesehatan, Universitas Muhadi Setiabudi Brebes, Indonesia \\ e-mail: anggraydw@gmail.com.
}

\begin{abstract}
ABSTRAK
Prosentase jumlah bayi gizi buruk yang tertinggi di Jawa Tengah tahun 2018 sebanyak 105 kasus, terbanyak ada di Brebes yaitu 92 kasus dan di Puskesmas Kluwut sebanyak 39 kasus gizi buruk. Penelitian ini bertujuan untuk mengetahui hubungan antara ASI eksklusif, pemberian makanan pendamping asi (MPASI), dan tingkat sosial ekonomi dengan status gizi pada bayi umur 7-12 bulan di Puskesmas Kluwut. Jenis penelitian ini adalah Explanatory Researc, menggunakan metode survey dengan pendekatan Cross Sectional. Populasi dari penelitian ini adalah bayi berumur 7-12 bulan yang berdomisili di Puskesmas Kluwut Kabupaten Brebes, yaitu sejumlah 529 bayi. Sampel dalam penelitian ini adalah bayi umur 7-12 bulan dari wilayah di Puskesmas Kluwut Kabupaten Brebes berjumlah 84 bayi dipilih secara simple random sampling. Variabel yang diteliti dalam penelitian ini adalah ASI Eksklusif dan pemberian MP-ASI sebagai variabel bebas dan status gizi sebagai variabel terikat. Pengumpulan data menggunakan metode observasi dan wawan cara menggunakan kuesioner. Analisis data dilakukan secara univariat dan bivariat (uji statistic Mann-Whitney) dengan taraf signifikansi ( $\alpha=5 \%$ ). Hasil penelitian menunjukkan Status gizi baik pada bayi 7- 12 bulan di Puskesmas Kluwut sebanyak 78 (92.9\%) bayi, bayi dengan ASI eksklusif sebanyak 69 (82,1\%) bayi, bayi dengan pemberian MP-ASI yang tepat sebanyak 70 (83,3\%) bayi dan tingkat sosial ekonomi tinggi sebesar 55 (65,5\%) bayi. Hubungan antara ASI eksklusif $(p=0,025)$ dan pemberian MP-ASI ( $p=0,008$ dengan status gizi menunjukkan ada hubungan dilihat dari nilai $p<0,005$. Simpulan dari penelitian ini terdapat hubungan yang signifikan anatara ASI eksklusif dan pemberian MPASI dengan status gizi.
\end{abstract}

Kata Kunci: Asi Eksklusif, MP-ASI, Status Gizi

\begin{abstract}
The percentage of the highest number of malnourished babies in Central Java in 2018 was 105 cases, the most in Brebes which was 92 cases and in Kluwut Health Center as many as 39 cases of malnutrition. This study aims to find out the relationship between exclusive breast milk, breastfeeding companion feeding (MP-BREAST MILK), and socioeconomic level with nutritional status in infants aged 7-12 months in Kluwut Health Center. This type of research is Explanatory Researc, using a survey method with a Cross Sectional approach. The population of this study is a baby aged 7-12 months domiciled in Kluwut Health Center brebes regency, which is a number of 529 babies. The sample in this study was infants aged 7-12 months from the region in Kluwut Health Center brebes regency numbering 84 babies selected simple random sampling. The variables studied in this study were Exclusive Breast milk and the administration of MP-breast milk as a free variable and nutritional status as a bound variable. Data collection uses observation methods and how to use questionnaires. Data analysis is conducted univariately and bivariate (Mann-Whitney statistical test) with a degree of significance $(\alpha=5 \%)$. The results showed good nutritional status in infants 7-12 months in Kluwut Health Center as many as 78 (92.9\%) infants, babies with exclusive breast milk as much as 69 (82.1\%) babies, babies with proper MP-breast milk as many as 70 (83.3\%) infants and high socioeconomic levels of 55 (65.5\%) infants. The relationship between exclusive breast milk $(p=0.025)$ and MP-breast milk ( $p=0.008$ with nutritional status indicates there is a relationship judging by the $p<0.005$ value. The conclusion of this study there is a significant relationship between exclusive breast milk and the provision of MP-breast milk with nutritional status.
\end{abstract}

Keywords: Exclusive Breast Milk, MP-BREAST MILK, Nutritional Status 


\section{PENDAHULUAN}

Pertumbuhan dan perkembangan bayi dan balita sebagian besar ditentukan oleh jumlah ASI yang diperoleh, termasuk energi dan zat gizi lainnya yang terkandung di dalam ASI tersebut. ASI tanpa bahan makanan lain dapat mencukupi kebutuhan pertumbuhan usia sekitar enam bulan. Pemberian ASI tanpa pemberian makanan lain selama enam bulan tersebut adalah menyusui secara eksklusif[1]. Pertumbuhan otak akan menentukan tingkat intelegensi seseorang yang dimulai sejak trimester ketiga umur kehamilan dan akan berakhir dalam periode 5-6 bulan pertama setelah kelahiran [2].

ASI merupakan makanan bayi yang terbaik dan setiap bayi berhak mendapatkan ASI. ASI Eksklusif adalah menyusui secara eksklusif sejak lahir sampai umur 6 bulan dan meneruskan menyusui anak sampai umur 2 tahun. Setelah 6 bulan, bayi mendapat makanan pendamping ASI yang bergizi sesuai dengan kebutuhan tumbuh kembangnya. Maka Departemen Kesehatan telah menerbitkan Surat Keputusan Menteri Kesehatan No. 450/MENKES//SK/IV/2004 tentang Pemberian Air Susu Ibu (ASI) Secara Eksklusif Pada Bayi di Indonesia[3].

Makanan pendamping air susu ibu (MP-ASI) adalah makanan atau minuman yang mengandung zat gizi selain dari ASI. Hal ini dikarenakan ASI hanya mampu memenuhi duapertiga kebutuhan bayi pada usia 6-9 bulan, dan pada 9-12 bulan memenuhi setengah dari kebutuhan bayi. Dalam pemberian MP-ASI, yang perlu diperhatikan adalah usia pemberian MPASI, jenis MP-ASI, frekuensi dalam pemberian MP-ASI, porsi pemberian MP-ASI dan cara pemberian MP-ASI pada tahap awal. Usia dibawah dua tahun masa yang amat penting sekaligus masa kritis dalam proses tumbuh kembang bayi baik fisik maupun kecerdasan, oleh karena itu setiap bayi dan anak usia 6-24 bulan harus memperoleh asupan gizi sesuai dengan kebutuhannya. Hasil survey menunjukkan bahwa salah satu penyebab terjadinya gangguan tumbuh kembang bayi dan anak usia 6-24 bulan di Indonesia adalah rendahnya mutu makanan pendamping air susu ibu (MP-ASI) dan tidak sesuai pola asuh yang diberikan sehingga beberapa zat gizi tidak dapat mencukupi kebutuhan khususnya energi dan zat gizi mikro terutama zat besi (Fe) dan $(\mathrm{Zn})[4]$.

Status gizi pada bayi dipengaruhi oleh faktor internal dan faktor eksternal. Faktor internal yaitu menyangkut faktor yang ada dalam diri anak yang secara psikologis muncul sebagai masalah makan pada anak sedangkan faktor eksternal menyangkut tingkat sosial ekonomi atau keterbatasan ekonomi keluarga, sehingga uang yang tersedia tidak cukup untuk membeli makanan. World Health Organization (WHO) menyatakan bahwa sebagian besar anak kurang gizi berasal dari keluarga miskin, anak - anak yang tumbuh dalam suatu keluarga miskin merupakan kelompok yang paling rawan terhadap gizi kurang. Kemiskinan berdampak pada sumber keuangan sehingga mengurangi kesempatan untuk makan yang sehat. Pada tahun 2016, 13.4\% atau 93 juta bayi di dunia mengalami gizi kurang[5]. Prevalensi tertinggi berada di wilayah Asia Selatan sebesar 31.4\%, diikuti Afrika Barat 19.5\%, Afrika Timur 17.8\% dan Asia Tenggara $15.2 \%$. Lebih dari 3 juta ata $12 \%$ bayi di Indonesia mengalami gizi kurang[6].

Berdasarkan hasil Riset Kesehatan Dasar (RISKESDAS), secara nasional prevalensi gizi kurang (BB/U <-2 SD) pada bayi fluktuatif. Pada tahun 2013 angka gizi kurang meningkat menjadi 19.6\%. Sebanyak 18 provinsi dari 33 provinsi di Indonesia memiliki angka prevalensi gizi kurang-buruk diatas angka prevalensi nasional, yaitu sebesar $21.2 \%$ sampai dengan $33.1 \%[7]$.

Berdasarkan laporan dari kabupaten/kota jumlah kasus gizi buruk di Jawa Tengah tahun 2018 sebanyak 105 kasus, terbanyak adalah di Brebes yaitu 92 kasus[8]. Kecamatan bebas rawan gizi berdasarkan definisi operasional dari "Rancangan matriks petunjuk teknis SPM bidang kesehatan di kabupaten/kota" adalah prosentase kecamatan dengan prevalensi gizi kurang dan gizi buruk pada bayi < $15 \%$ pada kurun waktu tertentu. Puskesmas dengan prosentase jumlah bayi gizi buruk yang tertinggi adalah Puskesmas Kluwut sebanyak 39 kasus gizi buruk. Sedangkan puskesmas yang tidak terdapat kejadian bayi gizi buruk ada 19 (sembilan belas) puskesmas[9]. Berdasarkan hal-hal terurai di atas maka penulis tertarik meneliti bagaimanakah 
hubungan antara ASI Eksklusif dan pemberian makanan pendamping ASI dengan status gizi pada bayi umur 7-12 bulan.

\section{BAHAN DAN METODE}

Penelitian ini menggunakan metode analitik observasional dengan pendekatan cross sectional. Variabel dalam penelitian ini terdiri dari variable independent dan variable dependent. Variabel independent yaitu pemberian makanan pendamping ASI (MP-ASI) dan ASI ekslusif; dan variable dependent yaitu status gizi pada bayi umur 7-12 bulan. Lokasi penelitian dilakukan di wilayah kerja Puskesmas Kluwut, Kabupaten Brebes. Sampel dalam penelitian ini berjumlah 84 ibu yang mempunyai bayi umur 7-12 bulan. Analisis ini digunakan untuk mendeskripsikan variabel independent dan variabel dependent. Data primer diperoleh dari kuesioner (pemberian makanan pendamping ASI (MP-ASI) dan ASI ekslusif) dan pengukuran panjang badan secara langsung (status gizi) sedangkan data sekunder (data jumlah bayi umur 712 bulan) diperoleh dari data puskesmas Kluwut. Analisis data untuk menguji hipotesis menggunakan uji Mann-Whitney dengan tingkat kemaknaan sebesar 5\% $(\alpha=0,05)$

\section{Gambaran Karakteristik Responden}

\section{HASIL DAN PEMBAHASAN}

Puskesmas kluwut adalah puskesmas yang terletak dan berlokasi di Jl. Pantura kluwut kecamatan bulakamba Kab. Brebes yang mayoritas penduduknya. Adalah petani, pedagang, dan juga rumah tangga, dan tempatnya sangat strategis untuk dilakukan penelitian. Penelitian dilakukanya di lima desa yang mayoritas penduduknya petani yaitu desa Bulak paren, Kluwut, Cimohong, Grinting dan Dukuhlo. Dari jumlah 529 responden setelah dilakukan sampel secara Simple Random Sampling di peroleh 84 responden.

Tabel 4.1 Distribusi Karakteristik Responden di Puskesmas Kluwut Kec. Bulakamba Kab. Brebes.

\begin{tabular}{|c|c|c|c|}
\hline No. & Variabel & $\mathbf{n}$ & $\%$ \\
\hline 1. & $\begin{array}{l}\text { Jenis Kelamin Balita } \\
\text { a. Laki-laki } \\
\text { b. Perempuan }\end{array}$ & $\begin{array}{l}41 \\
43\end{array}$ & $\begin{array}{l}48,8 \\
51,2\end{array}$ \\
\hline 2. & $\begin{array}{l}\text { Pemberian ASI } \\
\text { a. Eksklusif } \\
\text { b. } \quad \text { Tidak Eksklusif }\end{array}$ & $\begin{array}{l}69 \\
15 \\
\end{array}$ & $\begin{array}{l}82,1 \\
17,9 \\
\end{array}$ \\
\hline 3. & $\begin{array}{l}\text { Tambahan ASI } \\
\text { a. ASI } \\
\text { b. ASI + Susu Formula } \\
\text { c. Formula saja }\end{array}$ & $\begin{array}{c}72 \\
9 \\
3\end{array}$ & $\begin{array}{l}85,7 \\
10,7 \\
3,6\end{array}$ \\
\hline 4. & $\begin{array}{l}\text { Pendidikan Ibu } \\
\text { a. Pendidikan Rendah (SD-SMP) } \\
\text { b. Pendidikan Tinggi (SMA-PT) }\end{array}$ & $\begin{array}{l}71 \\
13\end{array}$ & $\begin{array}{l}84,5 \\
15,5\end{array}$ \\
\hline 5. & $\begin{array}{l}\text { Pekerjaan Ibu } \\
\text { a. Bekerja } \\
\text { b. Tidak Bekerja }\end{array}$ & $\begin{array}{l}13 \\
71 \\
\end{array}$ & $\begin{array}{l}15,5 \\
84,5\end{array}$ \\
\hline 6. & $\begin{array}{l}\text { Tingkat Sosial Ekonomi } \\
\text { a. } \quad \text { Tinggi (Jika pendapatan }>\text { Rp. } \\
\text { 1.542.000 perbulan dan } \leq 6 \text { orang } \\
\text { jumlah anggota keluarga) } \\
\text { b. } \quad \text { Rendah (Jika pendapatan } \leq \mathrm{Rp} . \\
\\
\text { 1.542.000 perbulan dan }>6 \text { orang } \\
\text { jumlah anggota keluarga) }\end{array}$ & 28 & 66,7 \\
\hline
\end{tabular}


Tabe; 1 menunjukkan, Jenis kelamin balita di bagi menjadi 2 kategori yaitu balita laki-laki dan balita prempuan. Dari hasil penelitian menunjukan balita yang paling banyak di posyandu kluwut adalah kelompok balita prempuan sebanyak 43 balita $(51,2 \%)$. Pada balita atau bayi pemberian Asi sangat di perlukan karena mempengaruhi kekebalan tubuh balita. Pada masa pertumbuhan pemberian Asi pada bayi baiknya dilakukan setelah bayi lahir. Pada penelitian ini banyak para ibu melakukan Asi Ekslusif yang tepat sebanyak 69 (82,1\%). Pada balita atau bayi, pemberian tambahan Asi sangat mempengaruhi tingkat Status Gizi balita karena bayi sebaiknya sangat bagus menggunakan hanya Asi saja. Itu terjadi pada kelompok ibu-ibu yang ada di Puskesmas Kluwut. Karena di penelitian tersebut ibu-ibu yang hanya menggunakan Asi saja sebanyak $72(85,7 \%)$. Tingkat pendidikan di bagi menjadi 2 kategori yaitu, pendidikan rendah (SD-SMP) dan pendidikan tinggi (SMP-PT) pendidikan ibu mayoritas masih rendah yaitu, sebanyak $71(84,5 \%)$ berpendidikan (SD-SMP).Tingkat pendidikan orang tua sangat mempengaruhi untuk menentukan Status Gizi anak, karena pendidikan sangat mempengaruhi seseorang untuk memahamidan menerima informasi tentang Gizi. Semakin tinggi pendidikan ibu diharapkan memiliki pengetahuan yang lebih baik dalam mengasuh anak-anak. Dari 84 responden ada $71(84,5 \%)$ responden yang tidak bekerja atau sebagai ibu rumah tangga saja. Pekerjaan orang tua sangat mempengaruhi pada Status Gizianaknya, Karena pendapatan dari orang tua yang bekerja akan mempengaruhi dalam pemberian MP-ASI, tentu saja waktu yang diberikan untuk mengurus anak lebih banyak dari ibu yang tidak bekerja. Berdasarkan penelitian Tingkat Sosial Ekonomi sangat berpengaruh pula dengan Status Gizi balita, karena seperti tingkat pendidikan, tingkat pekerjaan para ibu-ibu bila tingkat sosialnya tinggi yaitu wawasanya luas. Maka akan luas dan mengerti Gizi dalam memberikan makanan pada anaknya. Dan bila ibu-ibunya tingkat pendapatan tinggi maka terjamin tingkat Gizi anak-anaknya. Pada 84 responnden ditemukan $56(66,7 \%)$ tingkat sosial ekonomi yang tinggi.

Analisis Hubungan Pemberian ASI dengan status gizi bayi usia 7-12 bulan di Desa Kluwut Kecamatan Bulakamba Kabupaten Brebes.

Pemberian Asi di kategorikan menjadi 2 yaitu Asi Eksklusif dan Asi tidak Eksklusif. Variabel Status Gizi di kategorikan menjadi 3 yaitu Gizi baik, Gizi Kurang, dan Gizi Buruk. Pengukuran kategori ASI menggunakan instrument kuesioner dan untuk status gizi menggunakan panjang badan bayi usia 7-12 bulan.

Tabel 2. Hubungan Pemberian ASI dengan status gizi bayi usia 7-12 bulan di Puskesmas Kluwut Kecamatan Bulakamba Kabupaten Brebes.

\begin{tabular}{|c|c|c|c|c|c|c|c|c|c|c|}
\hline \multirow{3}{*}{ No. } & \multirow{3}{*}{ Pemberian ASI } & \multicolumn{6}{|c|}{ Status Gizi } & \multirow{2}{*}{\multicolumn{2}{|c|}{ Total }} & \multirow[b]{2}{*}{$\begin{array}{c}\text { Nilai } \\
\text { p }\end{array}$} \\
\hline & & \multicolumn{2}{|c|}{ Baik } & \multicolumn{2}{|c|}{ Kurang } & \multicolumn{2}{|c|}{ Buruk } & & & \\
\hline & & $\mathrm{F}$ & $\%$ & $\mathrm{~F}$ & $\%$ & $\mathrm{~F}$ & $\%$ & $\mathrm{f}$ & $\%$ & \multirow{4}{*}{0,025} \\
\hline 1. & ASI Eksklusif & 66 & 78,6 & 3 & 3,6 & 0 & 0 & 69 & 82,1 & \\
\hline \multirow[t]{2}{*}{2.} & Tidak Eksklusif & 12 & 14,3 & 1 & 1,2 & 2 & 2,4 & 15 & 17,9 & \\
\hline & Total & 78 & 92,9 & 4 & 4,8 & 2 & 2,4 & 84 & 100 & \\
\hline
\end{tabular}

Sumber: SPSS, Uji Mann-Whitney

Berdasarkan Tabel 2. dapat diketahui bahwa terdapat 84 responden bayi yang berstatus Gizi kurang $(4,8 \%)$ dan Gizi buruk $(2,4 \%)$, sedangkan dari 84 responden bayi yang berstatus Gizi baik $(92,9 \%)$. Status Gizi berdasarkan hasil penelitian diatas bahwa pemberian ASI terbagi menjadi 2 kategori yaitu ASI Ekslusif memiliki Status Gizi baik sebesar $66(78,6 \%)$ lebih tinggi dari bayi yang memiliki Status Gizi yang tidak Ekslusif 12 (14,3\%). Hubungan pemberian ASI dengan Status Gizi berdasarkan hasil penelitian menunjukkan bahwa terdapat hubungan yang signifikan antara pemberian ASI dengan status gizi bayi usia 7-12 bulan, hal tersebut dapat dilihat dari nilai $\mathrm{p}<0,05(0,025)$.

ASI merupakan makanan yang higienis, murah, mudah diberikan, dan sudah tersedia bagi bayi. ASI menjadi satu-satunya makanan yang dibutuhkan bayi selama 6 bulan pertama hidupnya 
agar menjadi bayi yang sehat. Komposisinya yang dinamis dan sesuai dengan kebutuhan bayi menjadikan ASI sebagai Asupan Gizi yang optimal bagi bayi. ASI dan plasma memiliki konsentrasi ion yang sama sehingga bayi tidak memerlukan cairan atau makanan tambahan. ASI lebih unggul dibandingkan makanan lain untuk bayi seperti susu formula, karena kandungan protein pada ASI lebih rendah dibandingkan pada susu sapi sehingga tidak memberatkan kerja ginjal, jenis proteinnya pun mudah dicerna. Selain itu, ASI mengandung lemak dalam bentuk asam amino esensial, asam lemakjenuh, trigliserida rantai sedang, dan kolesterol dalam jumlah yang mencukupi kebutuhan bayi [10]. ASI memiliki semua unsur-unsur yang memenuhi kebutuhan bayi akan Gizi selama periode sekitar 6 bulan, kecuali jika ibu megalami keadaan Gizi kurang yang berat atau gangguan kesehatan lain. Komposisi ASI akan berubah sejalan dengan kebutuhan bayi[11]. Tentang hubungan pemberian ASI Eksklusif dengan Status Gizi bayi usia 712bulan di Puskesmas Kluwut, menunjukkan adanya kecendrungan bahwa ibu yang memberikan ASI Eksklusif memiliki bayi Status Gizi lebih baik dari pada ibu yang tidak memberikan ASI Eksklusif. Hal ini terlihat ibu yang tidak memberikan ASI Eksklusif sebanyak 17,9\%. Sedangkan pada ibu yang memberikan ASI Eksklusif sebanyak 82,1\%. Penelitian yang dilakukan balita di desa dukuhmaja mengenai perilaku ASI ekslusif dikaitkan dengan status balita dalam hal ini stunting memiliki hubungan yang tidak signifikan antara perilaku ASI Ekslusif dengan stunting[12], demikian juga penelitian yang dilakukan oleh Depi (2020), menyatakan bahwa tidak ada hubungan antara ASI Ekslusif dengan stunting pada Batita [13].

Analisis Hubungan Pemberian MP-ASI dengan status gizi balita usia 7-12 bulan di Puskesmas Kluwut Kecamatan Bulakamba Kabupaten Brebes.

Pemberian Makanan Pendamping ASI (MP-ASI) di kategorikan menjadi 2 yaitu Asi Eksklusif dan Asi tidak Eksklusif. Variabel Status Gizi di kategorikan menjadi 3 yaitu Gizi baik, Gizi Kurang, dan Gizi Buruk. Pengukuran kategori ASI menggunakan instrument kuesioner dan untuk status gizi menggunakan panjang badan bayi usia 7-12 bulan.

Tabel 3. Hasil Hubungan Pemberian MP-ASI dengan status gizi balita usia 7-12 bulan di Puskesmas Kluwut Kecamatan Bulakamba Kabupaten Brebes.

\begin{tabular}{|c|c|c|c|c|c|c|c|c|c|}
\hline \multirow{3}{*}{$\begin{array}{c}\text { Pemberian MP- } \\
\text { ASI }\end{array}$} & \multicolumn{6}{|c|}{ Status Gizi Bayi } & \multirow{2}{*}{\multicolumn{2}{|c|}{ Total }} & \multirow{2}{*}{$\begin{array}{c}\text { Nilai } \\
\mathbf{p}\end{array}$} \\
\hline & \multicolumn{2}{|c|}{ Baik } & \multicolumn{2}{|c|}{ Kurang } & \multicolumn{2}{|c|}{ Buruk } & & & \\
\hline & $\mathrm{F}$ & $\%$ & $\mathrm{f}$ & $\%$ & $\mathrm{f}$ & $\%$ & $\mathrm{f}$ & $\%$ & \multirow{4}{*}{0,008} \\
\hline Tepat & 70 & 83,3 & 4 & 4,8 & 0 & 0 & 74 & 88,1 & \\
\hline Tidak Tepat & 8 & 9,5 & 0 & 0 & 2 & 2,4 & 10 & 11,9 & \\
\hline Total & 78 & 92,9 & 4 & 4,8 & 2 & 2,4 & 84 & 100 & \\
\hline
\end{tabular}

Sumber: SPSS, Uji Uji Mann-Whitney

Berdasarkan Tabel 3. dapat diketahui bahwa bayi yang diberikan MP-ASI secara tepat lebih tinggi $(83,3 \%)$ dibandingkan dengan pemberian MP-ASI yang tidak tepat $(9,5 \%)$. Berdasarkan hasil penelitian di dapat bahwa pemberian MP-ASI yang tepat pada bayi yang memiliki Status Gizi kurang adalah $4(4,8 \%)$ lebih tinggi dari pada bayi yang memiliki Status Gizi yang pemberian MP-ASI nya tidak tepat $0(0,0 \%)$. Yang menyatakan ada hubungan positif antara pemberian MP-ASI dengan Status Gizi.38 Hubungan pemberian MP-ASI dengan Status Gizi berdasarkan hasil penelitian menunjukkan bahwa terdapat hubungan yang signifikan antara pemberian MP-ASI dengan status gizi bayi usia 7-12 bulan, hal tersebut dapat dilihat dari nilai $\mathrm{p}$ $<0,05(0,008)$.

Tingkat kesehatan manusia atau pertumbuhan balita di tentukan oleh makanan yang masuk kedalam tubuh, jika jumlah atau nilai asupan makanan yang masuk kedalam tubuh berlebih atau berkurang akan memicu terjadinya Gizi lebih atau kekurangan Gizi. Pengenalan dan pemberian makanan pendamping ASI harus dilakukan secara bertahap baik bentuk maupun jumlahnya, bukan sekedar upaya menaikan berat badan dan panjang bayi tetapi juga proses belajar menggulum, mengunyah dan menelan. Pemberian MP-ASI pada anak harus bertahap 
kepadatanya sesuai dengan perkembangan umurnya dan disesuaikan dengan keadaan fisiologis anak, mulai dari MP-ASI bentuk lumat, lembik/lunak, sampai anak menjadi terbiasa dengan makanan keluarga[14]. Ada beberapa macam pendamping ASI lokal berdasarkan jenis MP-ASI, mulai dari makanan lumat seperti bubur sum-sum, kacang hijau dan bubur beras merah, makanan lembik/lunak seperti nasi tim, beras merah, nasi tim kangkung, saos papaya[15].

\section{KESIMPULAN}

Berdasarkan penelitian di puskesmas kluwut yang terletak di wilayah Kec. Bulakamba. Kab. Brebes adalah sebagai berikut :Ada hubungan antara pemberian ASI dan Pemberian MPASI dengan Status Gizi pada Bayi umur 7-12 bulan di Puskesmas Kluwut.

\section{DAFTAR PUSTAKA}

1. Siregar A, Pemberian ASI Ekslusif dan Faktor-faktor yang Mempengaruhinya, Bagian Gizi Fakultas Ilmu Kesehatan Masyarakat USU, 2004. Available athttp://library.usu.ac.id/fkm/fkm-arifinsiregar.pdf .Accessed on 19 January 2009.

2. Departemen Kesehatan Republik Indonesia. Pedoman Deteksi Dini Tumbuh Kembang Balita. Dir-Jen Bin Kes Ma, Direktorat Bin Kes Ga. Jakarta ; 1993: 1-25.

3. Saleh LA. Faktor-faktor yang Menghambat Praktik ASI Eksklusif Pada Bayi Usia 0-6 Bulan (Studi Kualitatif di Desa Tridana Mulya, Kecamatan Landono Kabupaten Konawe Selatan, Sulawesi Tenggara) (Skripsi). Semarang: Universitas Diponegoro; 20011.

4. Suhariati. Hubungan Pemberian Makanan Pendamping Air Susu Ibu (MP-ASI) Terhadap Pertumbuhan Balita usia 6-24 Bulan (Skripsi). Surakarta: Universitas Muhamadiyah Surakarta; 2010.

5. Winata J. 10 Facts About Nutrition in Indonesia. www.wpf.org/stories/10-factsaboutmalnutrition-indonesia.Published 2014.

6. WHO. Global Health Observatory Repository.apps.who.int/gho/data/view.main. NUTUNUNDERWEIGHTv. Published 2016.

7. Kementerian Kesehatan R. RisetKesehatan Dasar (RISKESDAS). Jakarta; 2013.

8. Dinas Kesehatan Provinsi Jawa Tengah. Profil Kesehatan Provinsi Jawa Tengah Tahun 2016. Semarang; 2016: 65-77.

9. Dinas Kesehatan Kabupaten Brebes. Profil Kesehatan Kabupaten Brebes 2015. Brebes; 2015: 14-15.

10. Brown JE, Dugan C and Kleindan R. 2005.Nutrition Through the Life Cycle. Balmont, USA: Thomson Wadsworth.

11. Gibney MJ, Barrie MM, John MK, and Leonore A. 2005. Public Health Nutrition. Oxford: Blackwell Publishing Ltd

12. Maulidah N, Wahyani AD. Hubungan Berat Badan Lahir (BBL) Bayi dan Perilaku Asi Eksklusif Terhadap Stunting Pada Balita. Jurnal Ilmiah Gizi dan Kesehatan (JIGK). 2020 Aug 31;2(01):7-10.

13. Purwanti DY, Ratnasari D. Hubungan Antara Kejadian Diare, Pemberian Asi Eksklusif, Dan Stunting Pada Batita. Jurnal Ilmiah Gizi dan Kesehatan (JIGK). 2020 Mar 2;1(02):15-23.

14. Nurastrini VR. 2013, 'Jenis MP-ASI, Frekuensi dan Waktu Pertama Kali Pemberian MPASI Sebagai Faktor Risiko Kejadian Gizi Lebih pada Bayi Usia 6-12 bulan di Kota Magelang, Skripsi Fakultas Kedokteran Universitas Diponegoro, Semarang.

15. Kemenkes RI. 2014, Pedoman Gizi Seimbang, Kementrian Kesehatan RI, Jakarta. 